\title{
Examining the Branding of Turkish Universities in the Context of Socio-economic Development of Their Cities
}

\author{
Nazife Karadag ${ }^{1}$ \\ 1 Nazife Karadag, Adiyaman University, Faculty of Education, Adiyaman, Turkey \\ Correspondence: Nazife Karadağ, Adıyaman University, Faculty of Education, Adıyaman, Turkey \\ Received: September 22, 2016 \\ Accepted: October 10, 2016 \\ Online Published: October 18, 2016 \\ doi:10.5430/ijhe.v5n4p173 \\ URL: http://dx.doi.org/10.5430/ijhe.v5n4p173
}

A part of this study was presented in $1^{\text {st }}$ International Higher Education Studies Conference.

\begin{abstract}
The purpose of this study is to investigate the branding processes of universities in Turkey with the consideration of the context of cities where the universities are located. This research is conducted to respond to this question: How is the branding process of Turkish universities in the context of the branding of their cities? Data constructed in accordance with qualitative approach were collected through document analysis technique. The study is structured based on a descriptive method. In the study, universities' branding process is assessed based on the related literature, the ratio of being chosen, base points for entry, and the number of students, faculty staff and faculties. According to the result of the study, the branding processes of Turkish universities are overshadowed by the branding of their cities. In addition, factors, including universities' faculty sources, the number of students and base point for entry, which are considered to be important for the branding of universities, are differentiated depending on the context of the cities.
\end{abstract}

Keywords: University, Branding, Branding of universities, Socio-economic development, City brand

\section{Introduction}

In 21st century where knowledge-based economic order and intense competition is dominant, firms have been in search for diversifying their products and services from their rivals in order to survive. This search has brought firms face to face with branding competitions. The concept of "brand" may refer to different meanings for firms as each firm serves in different ways. Brand, from customers' perspective, is seen as a factor facilitating the selection of a product, signifying a certain level of quality, decreasing product risks and increasing sense of trust (Keller and Lehmann, 2004). Brand is a combination of abstract and concrete elements that differentiate firms and products, manifest differences among them, influence the way consumers perceive firms and products (Kavak and Karabacakoğlu, 2007). In Delegated Legislation regarding Protection of Brands numbered 556, the concept of brand is defined as "including names for people, any type of sign that can be displayed through words, shapes, letters, numbers, the shape or package of goods provided that an enterprise's goods and products are discerned from another enterprise's goods and products."

Branding, which refers to high rates of market share, sales and profit (Ayvaz, 2005), plays a significant role in determining the efficiency of firms' market activities. Viewed from this perspective, it is possible to note that brand serves as a financial source of existence for firms (Keller and Lehmann, 2004). It is also known that brand has various functions such as differentiating a certain product from others, increasing competition among firms, working as an advertisement and publicity tool and constituting an element of quality (Ak, 2009). In addition to brand's benefits in terms of producer and product, various other benefits for consumers like providing an assurance for quality, defining products' features, providing guarantee for the product, continuation of this process following the purchase of a product and maintaining the demand for the product are also stated (Ak, 2009; Türk, 2004).

Universities have been seeking a substantial position to draw attention form students, academic personnel, and financial sources by emphasizing their differences from other universities (Waeraas and Solbakk, 2009). Effective realization of roles expected from universities has brought a concern for branding in today's world where internationalization and competition have become a prominent factor. Research on educational branding has yielded its initial results through universities (Arenson, 2004; Chapleo, 2003). The branding, from an educational standpoint, 
is considered with the academic reputation of the institution and for an educational institution to become a valuable brand, its mission and fundamental values should be clearly defined (Popescu, 2012). Branding from the perspectives of universities refers to differences a university owns compared to other universities and is viewed as a factor increasing students' interest in universities (Bennett and Ali-Chouldry, 2007). According to Black (2008), the branding of higher education institution is highly related to the people, is not constrained with a product or is not a service provided in the market. The intensification of national and international competition in higher education has led some universities to allocate ample budgets for branding activities (Chapleo, 2010). In addition to the idea that the universities which have a good brand attract more qualified students (Sevier, 2007), strong feelings and a unique communicative identity formed through branding (Bulotaite, 2003) encourage universities to embark on important initiatives towards branding. Likewise, since image and reputation are seen as more important factors than teaching quality for some universities (Mazzarol, 1998), this necessitates governance of universities as corporate brands (Whelan \& Wohlfeil, 2006).

A university's brand is seen as an expression of features that differentiate a given university from others, of sense of trust indicating that higher education service is rendered at a certain level, of students' capacity for satisfaction and of helping potential candidates make wise decisions during registration process (Bennett and Ali-Choudhury, 2007). According to Lamboy (2011), the branding of higher education institutions represents the power that refrain prospect students from selecting other universities in the process of university selection. The branding strategies affect the process of registrations, institutional identity, and marketing strategies. Nardali and Tanyeli (2011) stressed that the main need of universities for branding is to draw attention from students, parents, and business sector. As emphasized by Abbas (2014), if universities need to differentiate themselves from others, they need effective marketing and branding management strategies. Popescu (2012), who consider branding as the guarantee for high quality, asserted that the strong university brands promote internationalization of universities. Doyle (2001) emphasizes that a successful brand has three main characteristics; effective products, a distinguishing identity, and added value. Considered from this perspective, brand universities might bring in added value to its graduates in their work life and help them become more employable as opposed to graduates of other universities.

In today's society, universities have been in a continuous competition in terms of their sources, rankings, reputation, students and academic staff (Kizilbash, 2000). Sevier (2007)'s contention that a good university brand would attract more qualified students gives rise to the thought that universities whose base points are high has a long way towards becoming a brand university. Similarly, in studies on branding in higher education, it is emphasized that brand universities have strong faculty staff and that students have higher level of interest towards university (Bennett and Ali-Chouldry, 2007; Bhyani, 2010). In addition, important components of branding such as sources for academic staff (Black, 2008), the reputation of the universities (Keling, Krishnan \& Nurtjahja, 2007; Popescu, 2012), educational and other facilities on campus (Absher \& Crawford, 1996; Hossler \& Gallagher, 1990; Nardalı and Tanyeri, 2011), employment opportunities (Băcilă, 2008; Tekelioğlu, Başer, Örtlek \& Aydınlı, 2012; Yıldız, 2014), and financial assistance offered by university (Yusof, Ahmad, Tajudin \& Ravindran, 2008) have an effect on students' university preferences. Within this context, the current study attempts to assess universities branding processes through the evaluation of base points for student entrance in the university, the number of faculty staff and capacity of scientific research (based on URAP ranking list) and these parameters have been discussed by taking into consideration the socio-economic development of city where the university is located.

\subsection{Turkish Higher Education System}

Considering the development process of higher education in Turkey, it is seen that there has been an increasing social demand in higher education since the 1960s. Various development strategies have been adopted to address such demand. However, a substantial proportion of these strategies were carried out starting from 1980s (Özoğlu, Gür \& Gümüş, 2015). The most obvious development step was taken in 2005 with the government's policy of "a university in each city".

There has been a significant quantitative development in Turkish higher education since the government's decision to establish a university in each city. From 2006 to 2011, a total of 88 new universities, including 50 state and 38 foundation universities were established as a result of that policy. These numbers correspond to an about $115 \%$ increase in the number of higher education institutions only after 2006 (Günay\&Günay, 2011). By 2015, there were 175 universities in Turkey. 114 of these universities were state and 61 were foundation universities. By 2016, higher education institutions have a total of 3,900,601 students and 146,124 instructors (YÖK, 2016).

Universities in Turkey provide various alternatives in order to attract the attention of students, families, and faculty staff. However, these opportunities seem to fall behind the brand of the city in which the universities are located. As 
emphasized by Bhayani (2010), based on a university's established historical development, among the features that make a university attractive, the profile of graduates, campus location, natural beauties, historical buildings, art centers, internationally renowned faculty, and researchers and public opinion are the most important ones. When these factors are analyzed in Turkey's context, belief that these services could be better provided in metropolises which has a lot of opportunities seems to have brought universities in small cities to a disadvantageous position in terms of competition.

\section{Method}

This study is an attempt to assess Turkish universities' branding process through base points of universities, the number of faculty and students, their rank in international universities' list and their general scores. To achieve this purpose, the study is structured as a descriptive qualitative design. The descriptive design is to describe a phenomenon as its current and old forms (Karasar, 2012). In this way, it is intended to define the structures and operations of objects, communities and institutions (Cohen, Manion \& Morrison, 2007).

\section{Population and Sample}

The sample group of the study was comprised of 114 state universities located in Turkey. 14 universities were selected through using criterion-based sampling technique. The following criteria were considered for the selection of universities and cities:

For cities: Being at the top and lowest position of a geographical region in 2013 Turkey Socio-Economic Development List.

For universities: Being a university located in a city selected from geographical regions (In cases where there is more than one university in a city, the university that was established first was included in the study).

For departments: Being a department that has the highest acceptance score in Faculty of Education, Faculty of Science and Letters, Faculty of Administrative Sciences and Engineering in the year 2014-2015.

\section{Data Collection and Analysis}

The data of the study was collected through document analysis technique of qualitative research. University entrance base points were obtained from "The Base Points for Universities that Admit Students through Centralized Admission" revealed by ÖSYM in 2015 (ÖSYM, 2015). The numbers of students and faculty staff were taken from "Higher Education Statistics" revealed by Higher Education Council in the 2014-2015 academic year (YÖK, 2015). Finally, the data for universities' international ranking, based on their scientific publication performance, was acquired from "URAP 2014 World Raking." As for "Universities General Raking", that data was gained from "2014-2015 The General Point Table of All Universities" (URAP, 2014). Finally, the socio-economic development rakings that were used for all sub problems, such as socio-economic, demographic, employment, education, health, competition and innovation capacity, economic, accessibility, and life quality indicators were obtained from The Ministry of Development (The Ministry of Development, 2013). In order to analyze the data, universities' base points, the number of students and faculty staff, and international raking were compared according to the economic development raking of the cities in which the universities are located. This provided us with the information of how the economic development of the city in which university is located has associated with branding of the university.

\section{Results}

5.1 Findings and Interpretation Regarding Base Points of Faculties within the Context of Cities' Socio-Economic Development

In line with the first sub problem of the study, universities' branding process was analyzed through the evaluation of base points of faculties and the socio-economic development of cities in which universities are located. Table 1 presents cities that are at the bottom and top of the list in terms of socio-economic development ranking based on geographical regions and base points in various departments gathered from 2015-2016 YGS central exams in these universities and cities. 
Table 1. Turkey's SEGE ranking and the universities' base points in 2015-2016 year

\begin{tabular}{|c|c|c|c|c|c|}
\hline Region & City & $\begin{array}{l}2013 \text { SEGE } \\
\text { Ranking }\end{array}$ & University & Faculty & 2015-2016 YGS Base Points \\
\hline \multirow{10}{*}{ 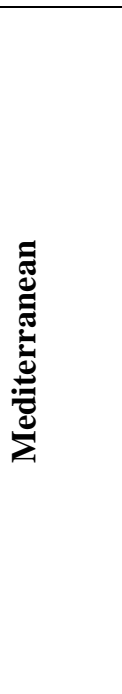 } & \multirow{5}{*}{ 苞 } & \multirow[t]{3}{*}{5} & \multirow[t]{3}{*}{$\begin{array}{l}\text { Akdeniz } \\
\text { University }\end{array}$} & $\begin{array}{l}\text { Faculty of Science and } \\
\text { Letters }\end{array}$ & 396,48 (Psychology) \\
\hline & & & & Faculty of Education & 401,34 (Turkish Education) \\
\hline & & & & $\begin{array}{l}\text { Faculty of Administrative } \\
\text { Sciences }\end{array}$ & 330,33 (International Relations) \\
\hline & & & & Faculty of Engineering & 360,72 (Civil Engineering) \\
\hline & & & & Faculty of Medicine & 472,54 \\
\hline & \multirow{5}{*}{ 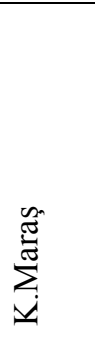 } & 60 & $\begin{array}{l}\text { Sütçü İmam } \\
\text { University }\end{array}$ & $\begin{array}{l}\text { Faculty of Science and } \\
\text { Letters }\end{array}$ & 337,47 (Geography) \\
\hline & & & & Faculty of Education & 336,19 (Primary School Teaching) \\
\hline & & & & $\begin{array}{l}\text { Faculty of Administrative } \\
\text { Sciences }\end{array}$ & 290,41 (Health Management) \\
\hline & & & & Faculty of Engineering & 302,58 (Civil Engineering) \\
\hline & & & & Faculty of Medicine & 448,01 \\
\hline \multirow{12}{*}{ 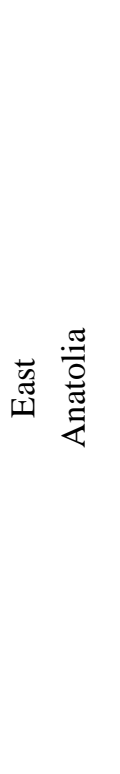 } & \multirow{7}{*}{$\begin{array}{l}\frac{100}{\mathbb{N}} \\
\frac{\pi}{I}\end{array}$} & \multirow[t]{7}{*}{39} & \multirow{7}{*}{$\begin{array}{l}\text { Furat } \\
\text { University }\end{array}$} & Faculty of Science & 225,21 (Maths) \\
\hline & & & & Faculty of Education & 384, 61 (Turkish Education) \\
\hline & & & & $\begin{array}{l}\text { Faculty of Administrative } \\
\text { Sciences }\end{array}$ & $\begin{array}{l}\text { 282,70 (Politics and Public } \\
\text { Management) }\end{array}$ \\
\hline & & & & Faculty of Humanities and & 339,25 (Geography) \\
\hline & & & & Social Sciences & 321,78 (Civil Engineering) \\
\hline & & & & Faculty of Engineering & 444,93 \\
\hline & & & & Faculty of Medicine & \\
\hline & \multirow{5}{*}{$\sum_{\Sigma}^{\infty}$} & \multirow[t]{5}{*}{81} & \multirow{5}{*}{$\begin{array}{l}\text { Muş } \\
\text { Alparslan } \\
\text { University }\end{array}$} & $\begin{array}{l}\text { Faculty of Science and } \\
\text { Letters }\end{array}$ & 323,83 (Literature) \\
\hline & & & & Faculty of Education & 373,34 (Turkish Education) \\
\hline & & & & $\begin{array}{l}\text { Faculty of Administrative } \\
\text { Sciences }\end{array}$ & $\begin{array}{l}257,28 \text { (Politics and Public } \\
\text { Management) }\end{array}$ \\
\hline & & & & Faculty of Engineering & $\begin{array}{l}\text { 234,21 (Computer } \\
\text { Engineering) }\end{array}$ \\
\hline & & & & Faculty of Medicine & - \\
\hline & & 3 & $\begin{array}{l}\text { Ege } \\
\text { University }\end{array}$ & Faculty of Science & 316.83 (Bio-chemistry) \\
\hline \multirow{5}{*}{ 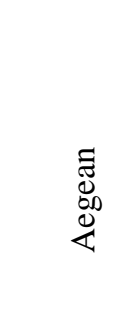 } & \multirow{5}{*}{ 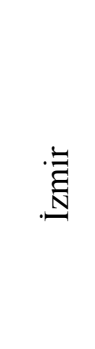 } & & & Faculty of Education & 420,92 (Turkish Education) \\
\hline & & & & $\begin{array}{l}\text { Faculty of Administrative } \\
\text { Sciences }\end{array}$ & $\begin{array}{l}\text { 345,66 (International } \\
\text { Relations) }\end{array}$ \\
\hline & & & & Faculty of Letters & 414, 51 (Psychology) \\
\hline & & & & Faculty of Engineering & $\begin{array}{l}\text { 397,50 (Electrical-Electronic } \\
\text { s Engineering) }\end{array}$ \\
\hline & & & & Faculty of Medicine & 484,17 \\
\hline
\end{tabular}




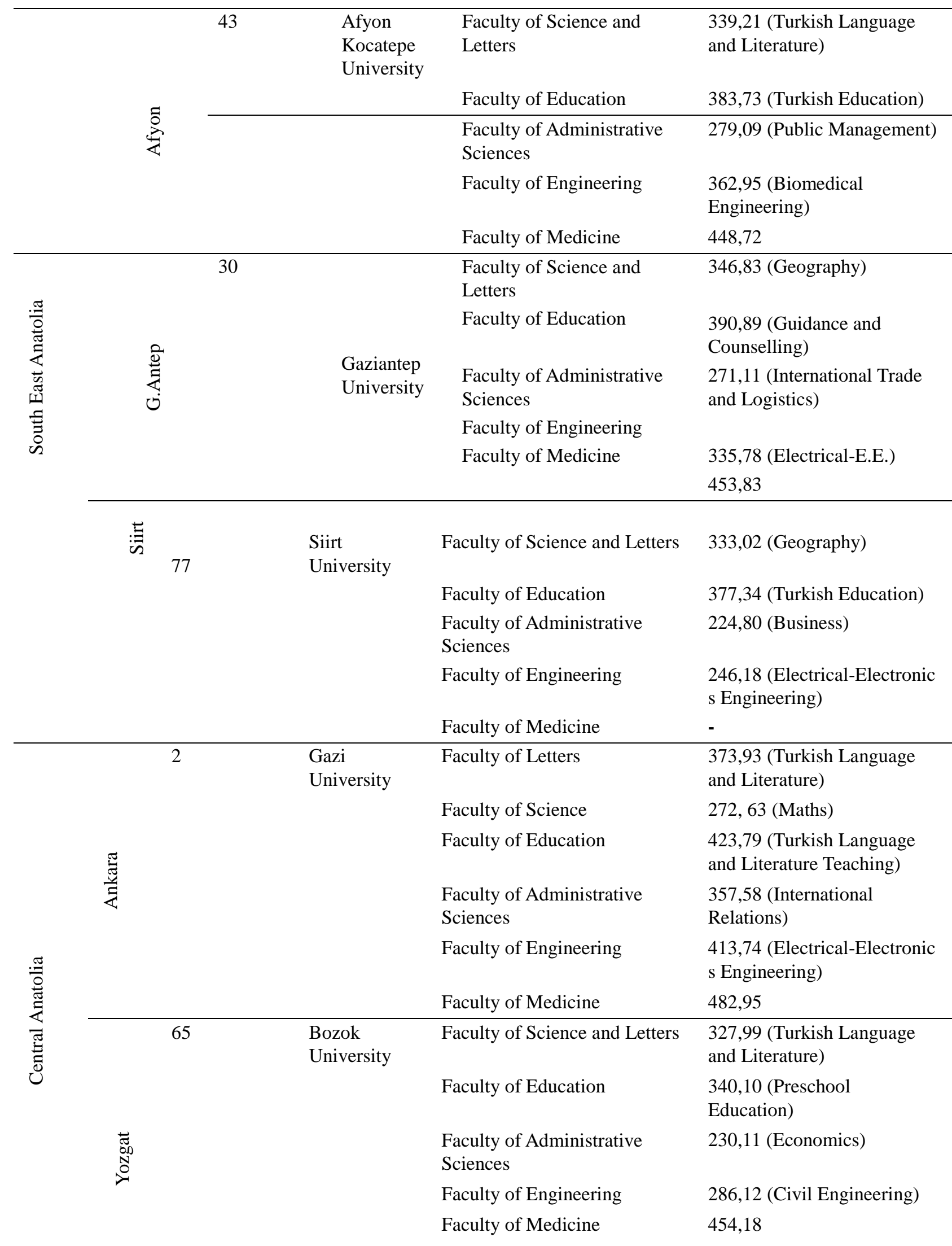




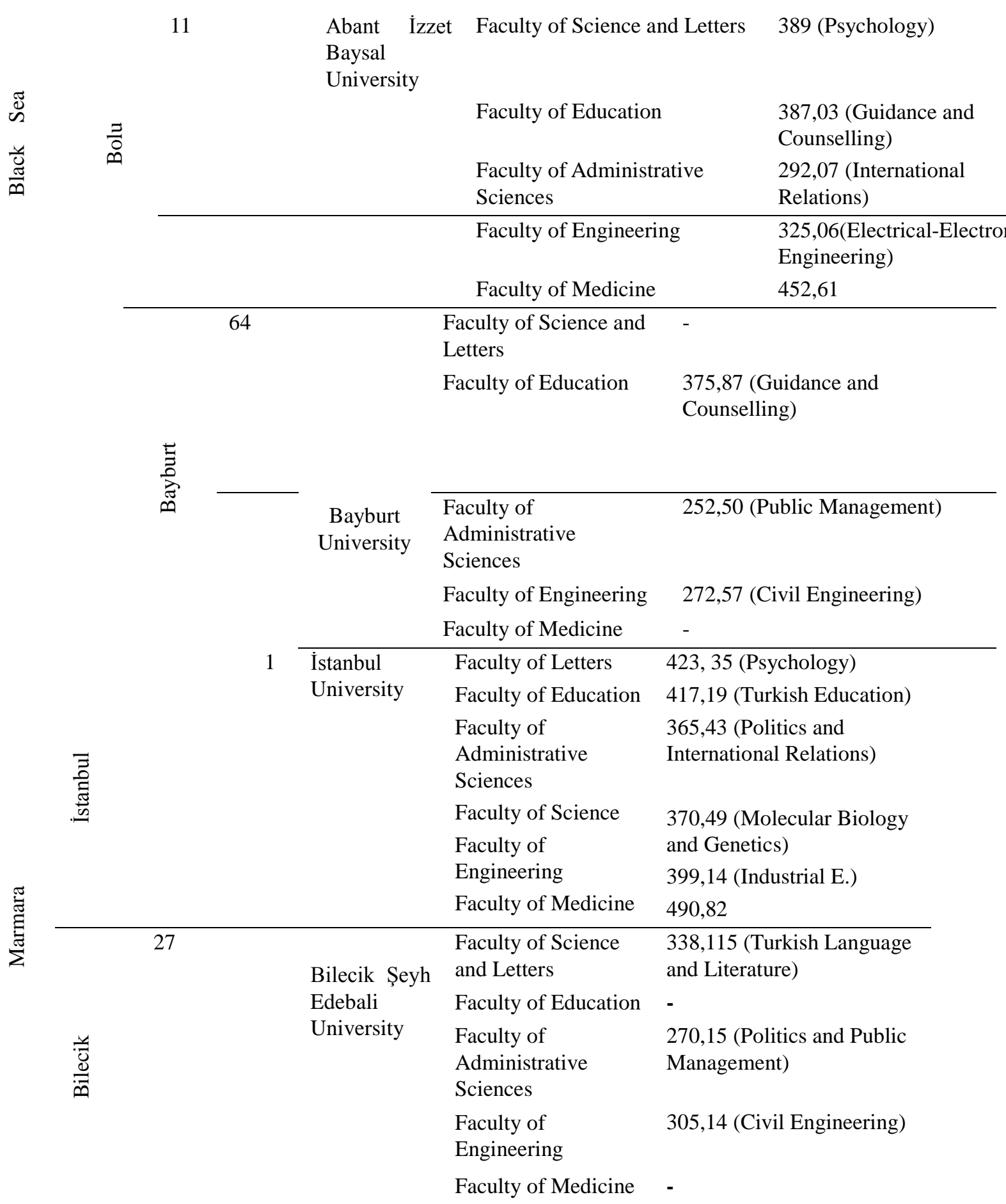

(SEGE: Socio-Economic Development Ranking/Ministry of Development)

The table shows that base points of universities located in all cities which are on top ranking in the socio-economic development list are higher than base points of universities located in cities which are on lowest ranking in the socio-economic development list. For example, while base point of Turkish Education department of Frrat University ranking 39th in socio-economic development ranking and located in Elazığ in the East Anatolia Region is 384,61, base point of Turkish Education department of Muş Alparslan University being in the lowest rank in socio-economic development list and located in Mus city in the same region is 373,34. Similarly, the base point of department of Turkish Language and Literature in Gazi University in the city of Ankara which ranks 2th in terms of socio-economic development is 373,93 , while base point of the same department in Bozok University that is located 
in the city of Yozgat which ranks 65th in terms of socio-economic development is 327,99. Base points of the departments in the faculties are determined by using the previous years' data on the rate of students' preferences of universities. In this context, it is seen that the socio-economic development of cities is one of the important factors in terms of not only branding of universities but also students' preferences of universities.

5.2 Findings and Interpretation Regarding the Number of Instructors and Students within the Context of the City Universities Are Located

In line with the second sub-question of the research, the number of instructors and students in 2014-2015 academic years are presented on Table 2 based on SEGE rankings of cities where universities are located.

Table 2. The number of instructors and students in 2014-2015 academic year based on 2013 SEGE rankings of some cities

\begin{tabular}{cccc}
\hline City & $\begin{array}{c}\text { 2013 SEGE } \\
\text { Ranking }\end{array}$ & $\begin{array}{c}\text { Then Number of } \\
\text { Instructors }\end{array}$ & $\begin{array}{l}\text { The Number of Students in } \\
\text { 2014-2015 Academic Year } \\
\text { (Vocational+Bachelor+Master's) }\end{array}$ \\
\hline Antalya & 5 & 2526 & 56598 \\
Kahramanmaraş & 60 & 1242 & 29216 \\
Elazı̆g & 39 & 1687 & 36043 \\
Muş & 81 & 474 & 9086 \\
İzmir & 3 & 7731 & 130868 \\
Afyon & 43 & 1333 & 38982 \\
Gaziantep & 30 & 1576 & 40053 \\
Siirt & 77 & 406 & 9130 \\
Ankara & 2 & 12421 & 214042 \\
Yozgat & 65 & 704 & 12095 \\
Bolu & 11 & 1295 & 24270 \\
Bayburt & 64 & 313 & 6433 \\
İstanbul & 1 & 14633 & 273450 \\
Bilecik & 27 & & 13863 \\
\hline
\end{tabular}

(The number of instructors and students was retrieved from https://istatistik.yok.gov.tr/ on 01.10.2015).

As shown on Table 2, the number of instructors and students of universities differ according to socio-economic development of cities where universities are located. In a region, the number of instructors and students in universities located cities in the top ranking of socio-economic development list is higher than the number of instructors and students of universities located in cities in the lowest ranking of socio-economic development list. For example, while there are 1575 instructors and 40053 students in Gaziantep University located in Gaziantep which in on the top ranking according to SEGE list (South-East Anatolia), there are 406 instructors and 9130 students in Siirt University located in Siirt city.

5.3 Findings and Interpretation Regarding the Scientific Publication Capacity of Universities (URAP World Rankings)

To answer the third sub-question of the problem, scientific publication capacity of universities is analyzed based on the cities they are located (Table 3 ). 
Table 3. Findings and interpretation of analyses of university rankings according to the city

\begin{tabular}{ccccc}
\hline City & University & 2013 SEGE Rankings & URAP Rankings & General Point Ranking \\
\hline Antalya & Akdeniz & 5 & 1160 & 575.50 \\
Kahramanmaraş & Sütçü İmam & 60 & 1619 & 497.12 \\
Elazı̆̆ & Fırat & 39 & 1055 & 570.85 \\
Muş & Alparslan & 81 & - & 215.47 \\
İzmir & Ege & 3 & 487 & 735.77 \\
Afyon & Afyonkocatepe & 43 & 1515 & 450.65 \\
Gaziantep & Gaziantep & 30 & 831 & 644.15 \\
Siirt & Siirt & 77 & - & 243.60 \\
Ankara & Gazi & 2 & 532 & 696.74 \\
Yozgat & Bozok & 65 & 1836 & 352.41 \\
Bolu & Abant İzzet Baysal & 11 & 1464 & 480.30 \\
Bayburt & Bayburt & 64 & - & 211.99 \\
İstanbul & İstanbul & 1 & 489 & 740.41 \\
Bilecik & Şeyh Edebali & 27 & - & 170.88
\end{tabular}

As can be seen on Table 3, URAP rankings of Akdeniz, Fırat, Ege, Gaziantep, Gazi, Abant İzzet Baysal and İstanbul Universities that are on the top in terms of socio-economic development in their region are higher than Sütçü İmam, Muş Alparslan, Afyon Kocatepe, Siirt, Bozok, Bayburt ve Bilecik Şeyh Edebali Universities that are on lowest ranking in their region. Furthermore, it is observed that Muş Alparslan, Siirt, Bayburt ve Şeyh Edebali universities that are ranked lowest in terms of socio-economic development in their region are not even ranked in the first 2000 universities list. Thus, it could be maintained that universities' scientific publication capacity and their international ranking have high association with socio-economic development of the cities they are located at.

\section{Discussion, Conclusion and Suggestions}

The study showed that the branding process of universities in Turkey has been overshadowed by the socio-economic development of cities they are located at. Based on the first sub-problem of the study, it could be noted that base points of universities in socio-economically developed cities are higher than those of universities in less developed cities. In the light of the fact that base points of universities are determined through generated demand for universities by students, it was concluded that level of socioeconomic development and facilities in the city have an effect on students' preferences of universities. For instance, research on the reasons of students' preferences of universities carried out by Korkut-Owen, Kepir, Özdemir, Ulaş and Yılmaz (2012) concluded that the main determiners are students' interest in their professions, the expectations of families, entrance points of students to universities and teachers' recommendations, as well as location, popularity, social, cultural and educational facilities of universities. Soutar and Turner (2002) also found that the social facilities of the cities in which universities located have an important effect on students' university preferences. There are also other important factors rather than the socioeconomic development of the city in the context of branding. Indeed, Abbas (2014) propose that for universities to be a strong brand, they need to create "we together" culture, foster interdepartmental commitment, establish creative department so as to survive in the new world order, form an information desk to give people correct information about university, design souvenirs such as files, pen and watch, advertise on newspaper, billboards, buses and web marketing milieus, organize various cultural, national and regional or non-academic activities, form sport teams in different branches, publish a university magazine, increase their graduates' employment rates through collaboration with professional associations, come up with a slogan, design stickers/labels, create classroom that could increase sense of ownership in students, develop alumni portal, press greeting/celebration cards and invitations, have a TV channel, have a sense of responsibility at corporate level and create a school where candidate 
students can have easy access. Similarly, Droiri, Delmestri and Oberg (2013), express that symbolic expressions and creation of an organizational culture is of high importance for the branding of universities. However, the fact that most universities with high brand raking in Turkey are mostly located in socio-economically developed cities should be considered with the reality that these universities are older than others that are located in low socio-economic cities. Such reality is also a limitation of the present study. Future studies could focus only on recently established universities and examine how branding of the cities where the universities are located influences their branding.

In line with the second sub-problem of the study, it could be stated that the number of instructors and students is dependent on the socio-economic development of the city universities are located at. The number of instructors and students in universities in cities that are in higher level of socio-economic development of a region is higher than the number of instructors and students in universities in cities that are in lower level of socioeconomic development. Supporting this finding, Baker and Brown (2007) and Lamboy (2011) found out that the number of students registered to a university is positively correlated to the brand of that university. Consistently, given the thoughts of the number of students change in reference to the rate of preferences made by students, the city students live in is an important factor on students' preferences of universities, according to the research in related literature (Briggs and Wilson, 2007; Moogan and Baron, 2003; Soutar and Turner, 2002). Bharti and Purohit (2015) suggested that universities should focus on improving their branding in order to satisfy student demands and receive increased attention from students. Chen and Chen (2014) investigated the effects of branding on students satisfaction and found that the performance, symbol and functionality components of branding were related to increased student satisfaction. Similarly, Jillapalli and Jillapalli (2014) and Dennis, Papagiannidis, Alamanos and Bourlakis (2016) stated that components of branding are keys to student satisfaction and commitment.

Based on the third sub-problem of the study, it was revealed that universities' URAP ranking changes according to socio-economic development indicators of the city where universities are located. In addition to the results reached in the studies, as stated in the literature, universities sources of academic staff that determine the rankings of the universities in the URAP (2010) list and both the quality and quantity of publications of academic staff have an effect on universities institutional image (Akar, 2012). Considered that prevalence of a city over another in terms of socio-economic development is interdepend on several factors, such as economic, social, cultural, technological and population density, it could be asserted that universities should make a difference to break this vicious circle. Supporting this result of the study, Brown and Oplatka (2007) also stated that universities should resort to marketing and brand management strategies to gain a competitive advantage.

Based on the results of the study, several recommendations can be made: First of all, the results indicated that the branding of universities has substantially been influenced by the socioeconomic development of the city in which they are located. Considering this finding, it makes sense to recommend that universities must carry out various academic and social activities for prospect students, in order to draw more attentions from students and consequently to rescue themselves from being overshadowed by the socio-economic development of their cities. The second finding of this study was the positive relationship between the number of academic personnel and students, and the socioeconomic status of the city where the university is located. Therefore, facilities and opportunities provided for students and instructors in cities and universities must be increased in order for creation of universities with high brand value. Lastly, it is evidence that there is a need for improving the ranking of universities. One way of doing this can be achieved through additional funding necessary to build better social and academic environment for students and academic personnel. Funding allocated to universities with low brand value must be increased in order to turn them into universities with high level of brand value.

\section{References}

Abbas, S.A. (2014). Brand management of higher education insitutions. International Journal of Innovative and Applied Research, 2(6), 151- 172.

Absher, K. \& Crawford, G. (1996). Marketing the community college starts with understanding students' perspectives. Community College Review, 23(4), 59-67. http://dx.doi.org/10.1177/009155219602300406

Ak, T. (2009). Marka yönetimi ve tüketici karar sürecine etkileri. Yayımlanmış Yüksek Lisans Tezi. Karamanoğlu Mehmet Bey Üniversitesi Sosyal Bilimler Enstitüsü.

Akar, C. (2012). Üniversite seçimini etkileyen faktörler: İktisadi ve idari bilimler öğrencileri üzerine bir Çalışma. Eskişehir Osmangazi Üniversitesi İ̈BF Dergisi, 7(1). 97-120.

Arenson, K.W. (2004). Branded nation. New York Times, 7 November, 10.

Ayvaz, C. (2005). Kobi marka iliş̧kisi. Türk Patent Enstitüsü Markalar Dairesi Başkanlığı Uzmanlık Tezi. 
Băcilă, M. F. (2008). 12th grade students' behavior in the decision making process of educational choices. Management and Marketing, 3(4), 81-92.

Baker, S. ve B Brown. (2007). Images of excellence: constructions of institutional prestige and reflections in the university choice process. British Journal of Sociology of Education, 28(3), 377-391. http://dx.doi.org/10.1080/01425690701253455

Bharti, N., \& Purohit, H. (2015). Higher Education Branding and its Influence on Student's Choice of Selecting a University. Available at SSRN 2682911.

Bennett, R. \& Ali-Choudhury, R. (2007). Components of the university brand: An empirical study. Proceedings of the 3rd. Annual Colloquium of the Academy of Marketing's Brand, Corporate Identity and Reputation SIG, Brunel University, 12-13 September 2007.

Black, J. (2008).

The Branding of Higher Education, SEM Papers, http://www.semworks.net/papers/wp_The-Branding-of-Higher-Education.php

Briggs, S. ve A.Wilson, (2007). Which university? A study of the influence of cost and information factors on Scottish undergraduate choice. Journal of Higher Education Policy and Management, 29(1), 57-72. http://dx.doi.org/10.1080/13600800601175789

Bulotaite, N. (2003). University heritage: An institutional tool for branding and marketing. Higher Education in Europe, 28(4), 449- 54. http://dx.doi.org/10.1080/0379772032000170417

Chapleo, C. (2010). What defines "successful" universit brandss? International Journal of Public Sector Management, 23(2). http://dx.doi.org/10.1108/09513551011022519

Chen, C. F., \& Chen, C. T. (2014). The effect of higher education brand images on satisfaction and lifetime value from students' viewpoint. Anthropologist, 17(1), 137-145.

Cohen, L., Manion, L. \&Morrison, K. (2007). Research methods in education. London: Routhledge

Dennis, C., Papagiannidis, S., Alamanos, E., \& Bourlakis, M. (2016). The role of brand attachment strength in higher education. Journal of Business Research, 69(8), 3049-3057. http://dx.doi.org/10.1016/j.jbusres.2016.01.020

Doyle, P. (2001). Shareholder-value-basedbrand strategies. Brand Management, 9(1), 20-30. http://dx.doi.org/10.1057/palgrave.bm.2540049

Jillapalli, R. K., \& Jillapalli, R. (2014). Do professors have customer-based brand equity?. Journal of Marketing for Higher Education, 24(1), 22-40. http://dx.doi.org/10.1080/08841241.2014.909556

Günay, D., \& Günay, A. (2011). 1933’ten günümüze Türk yükseköğretiminde niceliksel gelişmeler. Yükseköğretim ve Bilim Dergisi, (1), 1-22.

KALKINMA BAKANLIĞI (2013). İllerin ve Bölgelerin Sosyo-Ekonomik Gelişmişlik SıralamasıAraştırması (SEGE 2011). Retrieved from:http://www.kalkinma.gov.tr/Lists/Yaynlar/Attachments/54 8/SEGE-2011.pdf

Karasar, N. (2012). Bilimsel araştırma yöntemi. Ankara: Nobel Yayınları.

Kavak, B., Karabacakoğlu, Ç. (2007). Endüstriyel ürünler için stratejik markalama süreci: Küçük işletmeler üzerinde keşifsel bir araştırma. Ankara Üniversitesi SBF Dergisi, 62(2). 111-133. http://dx.doi.org/10.1501/SBFder_0000002021

Keling, S. B. A. Krishnan, A. Nurtjahja, O. (2007). Evaluative criteria for selection of private universities and colleges in Malaysia. Journal of International Management Studies, 2(1), 1-11.

Keller, K.L., Lehmann, D.R. (2004). Brands and Branding: Research Findings and Future Priorities. Retrieved from: http://bear.warrington.ufl.edu/CENTERS/MKS/invited/BRANDS\%20AND\%20BRANDING.pdf

Kizilbash, Z. (2000). Branding Canadian higher education. Canadian Bureau for International Education.

Lamboy, J. V. (2011). Implications of branding initiatives in higher education among trademarked institutions in california.

Mazzarol, T. (1998). Critical success factors for international education marketing. International Journal of Educational Management, 12(4). 163-175. 
Moogan, Y.J. ve S. Baron, (2003). "An analysis of students characteristics within the student decision making process". Journal of Further and Higher Education, 27(3), 271-287. http://dx.doi.org/10.1080/0309877032000098699

Nardalı, S., \& Tanyeri, M. (2011). Yükseköğretimde Markalaşma. Dokuz Eylül Üniversitesi İşletme Fakültesi Dergisi 12(2). 309-319.

ÖSYM (2015). “Tablo-4. Merkezi Yerleştirme İle Öğrenci Alan Yükseköğretim Lisans Programları”. Retrieved from: http://dokuman.osym.gov.tr/pdfdokuman/2015/OSYS/OSYS2015YerlestirmeMinMaxTablo-42 3072015.pdf.

Owen, F. K., Kepir, D. D., Özdemir, S., Özlem, Ulaş., \& Yılmaz, O. (2012). Üniversite öğrencilerinin bölüm seçme nedenleri. Mersin Üniversitesi Eğitim Fakültesi Dergisi, 8(3).

Özoğlu, M., Gür, B.S, Gümüş, S. (2016). Rapid expansion of higher education in Turkey: The challenges of recently established public universities (2006-2013). Higher Education Policy, 29(1), 21-39. http://dx.doi.org/10.1057/hep.2015.7

Popescu, A. I. (2012). Branding cities as educational centres. The role of higher education institutions. Management \& Marketing, 7(3), 493.

Sevier, R. A. (2007). Advancing the brand. University Business, 10(2), 46-51.

Soutar, G. ve J. Turner, (2002). "Students' preferences for university: a conjoint analysis," The International Journal of Educational Management, 16(1), 40-45. http://dx.doi.org/10.1108/09513540210415523

Tekelioğlu, S., Başer, H., Örtlek, M., \& Aydınl1, C. (2012). Uluslararası Öğrencilerin Ülke ve Üniversite Seçiminde Etkili Faktörler: Vakıf Üniversitesi Örneği. Organizasyon ve Yönetim Bilimleri Dergisi, 4(2).

Türk, Z. (2004). Tüketici satın alma davranışını etkileyen faktörler ve perakendeci markası üzerine bir alan araştırması. Muğla Üniversitesi Sosyal Bilimler Enstitüsü Yüksek Lisans Tezi. Muğla.

URAP. (2014). 20142015 World Ranking. Retrieved from: http://www.urapcenter.org/2014/world.php?q=MS0yNTA

Waeraas, A. \& Solbakk, M. (2009). Defining the essence of a university: lessons from higher education branding. Higher education, (57), 449-462. http://dx.doi.org/10.1007/s10734-008-9155-z

Whelan, S. \& M. Wohlfeil. (2006). Communicating brands through engagement with 'lived' experiences. Brand Management, 13(4/5), 313-329. http://dx.doi.org/10.1057/palgrave.bm.2540274

Yıldız, A. (2014). En iyi üniversite seçiminde analitik ağ projesinin kullanımı. İleri Teknoloji Bilimleri Dergisi, 3(2).

YÖK (2015). Yükseköğretim Bilgi Yönetim Sistemi. Retrieved from: https://istatistik.yok.gov.tr/.

YÖK (2016). Yükseköğretim Bilgi Yönetim Sistemi. Retrieved from: https://istatistik.yok.gov.tr/

Yusof, M., Ahmad, S. N. B., Tajudin, M. \& Ravindran, R. (2008). A study of factors influencing the selection of a higher education institution. UNITAR e-journal, 4(2), 27-40. 